\title{
New Haliangicin Isomers, Potent Antifungal Metabolites Produced by
}

\section{a Marine Myxobacterium ${ }^{\dagger}$}

\author{
BAngi A. Kundim, ${ }^{\text {a }}$ Yu ITOU, ${ }^{\text {a }}$ Youji SAKagami, ${ }^{\text {a }}$ Ryosuke Fudou, ${ }^{\text {b }}$ TAKASHI IIzuKa, ${ }^{\text {b }}$ \\ Shigeru YAMANAKA ${ }^{\mathrm{c}}$ and MAKOTO OJIKA ${ }^{\mathrm{a}, *}$ \\ ${ }^{\text {a }}$ Graduate School of Bioagricultural Sciences, Nagoya University, \\ Chikusa-ku, Nagoya 464-8601, Japan \\ ${ }^{\mathrm{b}}$ Institute of Life Science, Ajinomoto Co. Inc., \\ Kawasaki-ku, Kawasaki 210-8681, Japan \\ ${ }^{\mathrm{c}}$ Faculty of Textile Science and Technology, Shinshu University, \\ Tokida, Ueda 386-8567, Japan
}

(Received for publication March 7, 2003)

\begin{abstract}
Haliangicin is a $\beta$-methoxyacrylate-type polyene antibiotic isolated from the unique marine myxobacterium Haliangium ochraceum. A further investigation of the extract of this microorganism has resulted in the isolation of haliangicin as well as its geometrical isomers. The configuration of the epoxide in haliangicin, which was unknown previously, was determined in this study. The planar structures with partial stereochemistry of these isomers were elucidated by spectroscopic analyses. The major isomer, cis-haliangicin, is a cis isomer of the epoxide portion of haliangicin. Haliangicins $\mathrm{B} \sim \mathrm{D}$ are geometrical isomers of the polyene moiety, and present as an inseparable mixture of cis and trans epoxide isomers. Their antifungal activities were also evaluated in comparison with haliangicin.
\end{abstract}

Myxobacteria, common but unusual Gram-negative bacteria characterized by gliding behavior and fruiting body formation to form multicellular bodies, have recently been recognized as producers of novel antibiotics, and to date about 80 novel basic structures and more than 400 variants of these compounds have been isolated from myxobacteria. ${ }^{123)}$ Myxobacteria have lately drawn greater interest due to the discovery of the epothilones, ${ }^{4,5)}$ which show potent antitumor activity and mimic the biological effects of taxol. ${ }^{6)}$ The myxobacteria had been regarded as terrestrial microorganisms until recently, when some myxobacterial strains were successfully isolated from marine environments. ${ }^{7}$ From a marine myxobacterial species of the genus Haliangium, a novel polyene antifungal antibiotic containing a $\beta$-methoxyacrylate moiety, haliangicin (1), was isolated, and its bioactivities and planar structure were reported ${ }^{8,9)}$ In our search for additional antifungal agents from the marine isolate, we have found several new isomers of 1. cis-Haliangicin (2) is a cis isomer about the epoxide moiety of $\mathbf{1}$, and haliangicins $\mathrm{B} \sim \mathrm{D}(\mathbf{3} \sim \mathbf{5})$ are geometrical isomers of the polyene moiety, as well as appear to be mixtures of cistrans isomers of the epoxide moiety (Fig. 1). This paper reports the isolation and structural elucidation of these haliangicin isomers as well as their antifungal activity.

\section{Isolation}

The marine myxobacterium Haliangium ochraceum AJ 13395 was used as a haliangicin-producer throughout this study. Although it had been tentatively named $H$. luteum in the previous papers, ${ }^{8,9)}$ the new species name, H. ochraceum, was recently proposed for the strain with its detailed taxonomic description. ${ }^{10)}$ The marine myxobacterium was cultured at $27^{\circ} \mathrm{C}$ for 17 days in a culture medium containing $2 \% \mathrm{NaCl}$. The culture broths (total 9 liters) were centrifuged to collect the bacterial cells and an adsorbent resin (productivity enhancer), which were

+ This paper is dedicated to the late Professor HiDESHI NAKAMURa (deceased 9th November 2000).

* Corresponding author: ojika@agr.nagoya-u.ac.jp 
Fig. 1. Structures of haliangicin (1) and its isomers $\mathbf{2} \sim \mathbf{5}$.

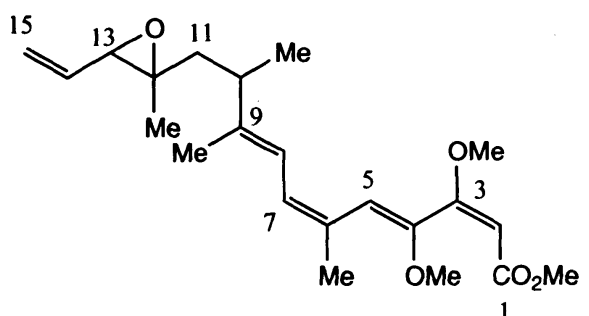

haliangicin (1)

\begin{tabular}{|c|c|c|c|c|}
\hline \multirow[t]{2}{*}{ Compound } & \multicolumn{4}{|c|}{ Geometry } \\
\hline & $\overline{\mathrm{C} 2}$ & $\mathrm{C} 4$ & C6 & Epoxide $^{a}$ \\
\hline haliangicin (1) & $E$ & $Z$ & $Z$ & trans \\
\hline cis-halinagicin (2) & $E$ & $Z$ & $Z$ & cis \\
\hline $\begin{array}{l}\text { haliangicin B (3) } \\
(+c i s \text { isomer) }\end{array}$ & $Z^{b}$ & $Z$ & $Z$ & $\begin{array}{l}\text { trans } \\
(+ \text { cis })\end{array}$ \\
\hline $\begin{array}{l}\text { haliangicin C (4) } \\
\text { (+ cis isomer) }\end{array}$ & $E$ & $E^{b}$ & $Z$ & $\begin{array}{c}\text { trans } \\
(+ \text { cis })\end{array}$ \\
\hline $\begin{array}{l}\text { haliangicin } \mathrm{D}(5) \\
(+ \text { cis isomer) }\end{array}$ & $E$ & $E^{b}$ & $E^{b}$ & $\begin{array}{c}\text { trans } \\
(+ \text { cis })\end{array}$ \\
\hline
\end{tabular}

Haliangicins $\mathrm{B} \sim \mathrm{D}(\mathbf{3} \sim \mathbf{5})$ are a mixture of trans and cis isomers about the epoxide moiety in a ratio of $2: 1$.

extracted with acetone. The acetone extract was chromatographed on silica gel. The haliangicin-containing fraction was applied to a second silica gel chromatography followed by preparative HPLC to obtain haliangicin (1), haliangicin B (3), haliangicin C (4), and haliangicin D (5) as mixtures of trans-and cis-epoxy isomers in the ratio of 2:1 (Fig. 2). Since the samples were quite susceptible to decomposition through oxidation in air and light at room temperature, they were handled in dim light and stored in benzene at $-20^{\circ} \mathrm{C}$. The fraction containing haliangicin (1) was further subjected to recycle HPLC to obtain pure haliangicin (1) and cis-haliangicin (2). Although haliangicins B (3), C (4) and D (5) contained their cisepoxy isomers as the minor component (2:1 ratio), we did not succeed in the purification of these isomers.

The antifungal activity of the haliangicins against the phytopathogenic fungus Phytophthora capsici was evaluated by using a paper disc assay method. The minimum doses applied on a paper disc to inhibit the fungus growth in this assay were as follows: 1 ( $8 \mathrm{ng} / \mathrm{disc})$, 2 ( $8 \mathrm{ng} / \mathrm{disc}), 3$ (40 $\mathrm{ng} / \mathrm{disc}), 4$ (40 $\mathrm{ng} / \mathrm{disc})$, and 5 ( $200 \mathrm{ng} / \mathrm{disc})$. A $\beta$-methoxyacrylate-type compound, cystothiazole $\mathrm{A},{ }^{11)}$ was used as a positive control (200 ng/disc).

\section{Structural Elucidation}

All the spectroscopic data for haliangicin (1) agreed well
Fig. 2. A Preparative HPLC trace showing the separation of haliangicin (1) and its isomers $(2 \sim 5)$.

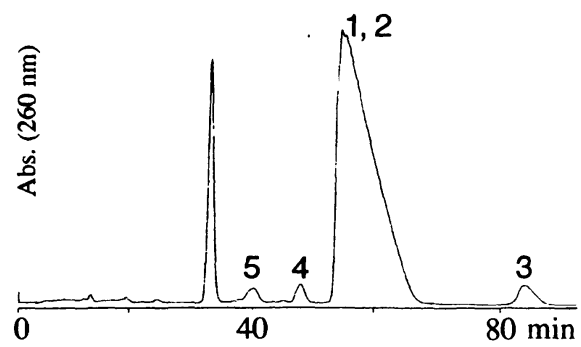

Each peak is a mixture of trans and cis isomers in a ratio of $2: 1$.

with the previous data reported by Fudou et al., ${ }^{9)}$ although the specific rotation was not in good agreement. The reported rotation was found to have been determined for a mixture of $\mathbf{1}$ and its cis-isomer $\mathbf{2}$ by comparison of NMR data. NOESY examination of $\mathbf{1}$ showed correlations of $\mathrm{H} 11 / \mathrm{H} 13$ and $\mathrm{H} 14 / 12-\mathrm{Me}$, suggesting a trans stereochemistry of the epoxy moiety (Fig. 3 and Table 4). The relative stereochemistry of the epoxide in $\mathbf{1}$, though not stated clearly in the previous report, ${ }^{9}$ has been determined for the first time in the present study. 
Table 1. NMR spectral data for cis-haliangicin (2) in $\mathrm{CDCl}_{3}$.

\begin{tabular}{llll}
\hline Position & $\delta_{\mathrm{H}}($ mult, $J$ in Hz) & $\delta_{\mathrm{C}}(\text { mult })^{\mathrm{b}}$ & $\mathrm{HMBC}($ to $\mathrm{C})$ \\
\hline 1 & - & $167.0(\mathrm{~s})$ & - \\
2 & $5.26(\mathrm{~s})$ & $95.8(\mathrm{~d})$ & 3,4 \\
3 & - & $165.9(\mathrm{~s})$ & - \\
4 & - & $148.0(\mathrm{~s})$ & - \\
5 & $5.80(\mathrm{~s})$ & $112.4(\mathrm{~d})$ & $3,4,7,6-\mathrm{Me}$ \\
6 & - & $130.6(\mathrm{~s})$ & - \\
7 & $6.05(\mathrm{~d}, 11.4)$ & $126.3(\mathrm{~d})$ & $5,9,6-\mathrm{Me}$ \\
8 & $6.13(\mathrm{~d}, 11.4)$ & $120.7(\mathrm{~d})$ & $6,9,10,9-\mathrm{Me}$ \\
9 & - & $141.8(\mathrm{~s})$ & - \\
10 & $2.39(\mathrm{~m})$ & $40.6(\mathrm{~d})$ & $8,9,11,12,9-\mathrm{Me}, 10-\mathrm{Me}$ \\
$11 \mathrm{a}$ & $1.46(\mathrm{dd}, 8.4,14.0)$ & $37.5(\mathrm{t})$ & $9,10,12,10-\mathrm{Me}, 12-\mathrm{Me}$ \\
$11 \mathrm{~b}$ & $1.80(\mathrm{dd}, 6.7,14.0)$ & & $9,10,12,13,10-\mathrm{Me}, 12-\mathrm{Me}$ \\
12 & - & $62.3(\mathrm{~s})$ & - \\
13 & $3.18(\mathrm{~d}, 7.1)$ & $64.5(\mathrm{~d})$ & $12,14,15,12-\mathrm{Me}$ \\
14 & $5.77(\mathrm{ddd}, 7.1,10.5,17.3)$ & $133.9(\mathrm{~d})$ & 13 \\
$15 \mathrm{a}$ & $5.33(\mathrm{~d}, 10.5)$ & $119.6(\mathrm{t})$ & 13 \\
$15 \mathrm{~b}$ & $5.43(\mathrm{~d}, 17.3)$ & & 13,14 \\
$1-\mathrm{OMe}$ & $3.68(\mathrm{~s})$ & $51.2(\mathrm{q})$ & 1 \\
$3-\mathrm{OMe}$ & $3.73(\mathrm{~s})$ & $56.0(\mathrm{q})$ & 3 \\
$4-\mathrm{OMe}$ & $3.55(\mathrm{~s})$ & $57.2(\mathrm{q})$ & 4 \\
$6-\mathrm{Me}$ & $2.09(\mathrm{~s})$ & $23.6(\mathrm{q})$ & $5,6,7$ \\
$9-\mathrm{Me}$ & $1.70(\mathrm{~s})$ & $13.3(\mathrm{q})$ & $8,9,10$ \\
$10-\mathrm{Me}$ & $0.97(\mathrm{~d}, 6.9)$ & $19.4(\mathrm{q})$ & $9,10,11$ \\
$12-\mathrm{Me}$ & $1.33(\mathrm{~s})$ & $22.5(\mathrm{q})$ & $11,12,13$ \\
\hline
\end{tabular}

a Recorded at $600 \mathrm{MHz}$.

${ }^{b}$ Recorded at $150 \mathrm{MHz}$. Multiplicity inferred using the DEPT pulse sequence.

cis-Haliangicin (2) and the other haliangicins (3 5 and their cis-isomers) were thought to be isomers of 1 because they possess the same molecular formula, $\mathrm{C}_{22} \mathrm{H}_{32} \mathrm{O}_{5}$, determined by positive ion ESI TOF-MS in high-resolution mode and by their similar NMR data to 1 (Tables $1 \sim 3$ ). The resonances at $\delta 167.0,165.8,166.1$, and 166.1 in the ${ }^{13} \mathrm{C}$ NMR spectra of $\mathbf{2} \sim \mathbf{5}$, respectively, indicated the presence of one carbonyl carbon in each compound, most likely an $\alpha, \beta$-unsaturated ester judging from the IR absorption bands at $1717,1720,1726$, and $1727 \mathrm{~cm}^{-1}$ for 2 5, respectively. Analysis of 2D NMR data (DQF-COSY, HMQC, and HMBC) proved that the compounds $\mathbf{2} \sim \mathbf{5}$ (and the cis-isomers of $3 \sim 5$ ) had the same gross structure as that of 1. NOESY experiments finally enabled us to distinguish each isomer, as discussed individually below (Fig. 3 and Table 4).

The NMR data for cis-haliangicin (2) are summarized in Table 1. Significant differences in the NMR chemical shifts between 1 and 2 are observed at the positions 11 and 12Me, $\delta_{\mathrm{H}} 1.46,1.80$ (H11), 1.33 (12-Me), $\delta_{\mathrm{C}} 37.5$ (C11), and $22.5(12-\mathrm{Me})$ for 2 , and $\delta_{\mathrm{H}} 1.28,1.93(\mathrm{H} 11), 1.22$ (12-Me), $\delta_{\mathrm{C}} 43.9(\mathrm{C} 11)$, and 16.7 (12-Me) for 1 , suggesting that 2 is a stereoisomer of the epoxide in $\mathbf{1}$. The NOE correlations of 2 (Table 4) revealed that the configuration of the tetraene moiety was the same as that of $\mathbf{1}$. However, different NOE correlations were observed at epoxy portion, that is, the correlations of H13/12-Me and H11/H14 (Fig. 3), support a cis configuration of the epoxide in $\mathbf{2}$. Thus, compound $\mathbf{2}$ is 
Table 2. ${ }^{1} \mathrm{H}$ NMR data for haliangicins $\mathrm{B}(3) \sim \mathrm{D}(5)$ and their cis isomers in $\mathrm{CDCl}_{3}$.

\begin{tabular}{llll}
\hline & & $\delta_{\mathrm{H}}($ mult, $J$ in Hz) & \\
Position & $\mathbf{3}[\text { cis-3 }]^{\mathrm{b}}$ & $\mathbf{4}[c i s-4]^{\mathrm{b}}$ & $\mathbf{5}[$ cis-5] \\
\hline 2 & $5.56[5.57](\mathrm{s})$ & $5.18(\mathrm{~s})$ & $5.22(\mathrm{~s})$ \\
5 & $6.36[6.37](\mathrm{s})$ & $5.80[5.83](\mathrm{s})$ & $5.57(\mathrm{~s})$ \\
7 & $6.16[6.17](\mathrm{s})^{\mathrm{c}}$ & $5.98(\mathrm{~d}, 10.9)$ & $6.19(\mathrm{~d}, 11.4)$ \\
8 & $6.16[6.17](\mathrm{s})^{\mathrm{c}}$ & $6.16[6.17](\mathrm{d}, 11.0)$ & $6.08[6.09](\mathrm{d}, 11.4)$ \\
10 & $2.43[2.45](\mathrm{m})$ & $2.36[2.38](\mathrm{m})$ & $2.37[2.39](\mathrm{m})$ \\
$11 \mathrm{a}$ & $1.37[1.49](\mathrm{dd}, 8.7,13.7)$ & $1.32[1.47](\mathrm{dd}, 9.2,14.0)$ & $1.32[1.46](\mathrm{dd}, 9.1,14.0)$ \\
$11 \mathrm{~b}$ & $1.93[1.78](\mathrm{dd}, 6.5,13.7)$ & $1.94[1.79](\mathrm{dd}, 6.8,14.00)$ & $1.97[1.80](\mathrm{dd}, 6.8,14.0)$ \\
13 & $3.20[3.18](\mathrm{d}, 7.1)$ & $3.20[3.18](\mathrm{d}, 7.1)$ & $3.21[3.18](\mathrm{d}, 7.1)$ \\
14 & $5.72[5.77]$ & $5.73[5.77]$ & $5.72[5.77]$ \\
& $(\mathrm{ddd}, 7.1,10.3,17.3)$ & $(\mathrm{ddd}, 7.1,10.2,17.3)$ & $(\mathrm{ddd}, 7.1,10.2,17.4)$ \\
$15 \mathrm{a}$ & $5.33[5.34](\mathrm{d}, 10.3)$ & $5.33(\mathrm{~d}, 10.2)$ & $5.33(\mathrm{~d}, 10.2)$ \\
$15 \mathrm{~b}$ & $5.44(\mathrm{~d}, 17.3)$ & $5.44[5.43](\mathrm{d}, 17.3)$ & $5.44(\mathrm{~d}, 17.4)$ \\
$1-\mathrm{OMe}$ & $3.73(\mathrm{~s})$ & $3.66(\mathrm{~s})$ & $3.66(\mathrm{~s})$ \\
$3-\mathrm{OMe}$ & $3.88(\mathrm{~s})$ & $3.66(\mathrm{~s})$ & $3.69(\mathrm{~s})$ \\
$4-\mathrm{OMe}$ & $3.58(\mathrm{~s})$ & $3.72(\mathrm{~s})$ & $3.68(\mathrm{~s})$ \\
$6-\mathrm{Me}$ & $2.09(\mathrm{~s})$ & $1.83(\mathrm{~s})$ & $1.78(\mathrm{~s})$ \\
$9-\mathrm{Me}$ & $1.74(\mathrm{~s})$ & $1.68(\mathrm{~s})$ & $1.70(\mathrm{~s})$ \\
$10-\mathrm{Me}$ & $1.04[1.00](\mathrm{d}, 6.9)$ & $1.02[0.98](\mathrm{d}, 6.8)$ & $1.02[0.98](\mathrm{d}, 6.9)$ \\
$12-\mathrm{Me}$ & $1.27[1.34](\mathrm{s})$ & $1.26[1.33](\mathrm{s})$ & $1.25[1.33](\mathrm{s})$ \\
\hline
\end{tabular}

${ }^{\mathrm{a}}$ Recorded at $600 \mathrm{MHz}$.

${ }^{\mathrm{b}}$ The $c i s$ isomers are minor in all cases in the ratio of 2:1 and the chemical shifts due to the cis isomers are shown in brackets if different from those due to the trans isomers $(3 \sim 5)$.

c The protons $\mathrm{H} 7$ and $\mathrm{H} 8$ were distinguished when measured in $\mathrm{C}_{6} \mathrm{D}_{6}(400 \mathrm{MHz})$ to determine the geometry of C6 and C8: $\delta 6.26(\mathrm{~d}, J=11.3 \mathrm{~Hz}, \mathrm{H} 7)$ and $6.40(\mathrm{~d}, J=11.3 \mathrm{~Hz}, \mathrm{H} 8)$ for 3 and $\delta 6.26(\mathrm{~d}, J=$ $11.3 \mathrm{~Hz}, \mathrm{H} 7)$ and $6.44(\mathrm{~d}, J=11.6 \mathrm{~Hz}, \mathrm{H} 8)$ for cis-3.

the epoxy cis-isomer of $\mathbf{1}$, that is, cis-haliangicin, though the relative stereochemistry between the epoxide (C12C13) and C10 is still unknown.

The structural analysis of haliangicin B (3) was performed as a mixture of two isomers. A thorough analysis of the 2D NMR data for this mixture enabled us to assign all the NMR signals to each of the isomers (Tables 2 and 3). The same NOE correlations were observed for the epoxide moiety between $\mathbf{1}$ and $\mathbf{3}$ and between $\mathbf{2}$ and the isomer of 3 (Fig. 3). On the other hand, a strong NOE correlation between $\mathrm{H} 2$ and $\mathrm{H} 5$ in the tetraene moiety (Table 4) suggested $2 Z$ configuration for both 3 and its isomer, unlike the $2 E$ configuration for $\mathbf{1}$ and $\mathbf{2}$. The other olefins in the tetraene moiety had the same configuration as 1 and 2. Thus, haliangicin B (3) is the $2 Z$ isomer of 1 and the coexistent isomer is the $2 Z$ isomer of $\mathbf{2}$, that is, cishaliangicin $\mathrm{B}$ (cis-3).

Haliangicin C (4) showed the same NOE correlations as those of 1 except for the strong NOE correlations of H5/4OMe (Table 4 ), suggesting $4 E$ geometry. The concomitant minor isomer of 4 showed the same NOE correlations as those of 4 at the tetraene portion (Table 4), while different NOE correlations were observed for the epoxide moiety, as in the case of 3 and cis-3 (Fig. 3). Thus, haliangicin (4) is the $4 E$ isomer of 1 and the concomitant isomer is the $4 E$ isomer of 2, namely, cis-haliangicin C (cis-4).

In a similar way, the examination of the NOE correlations (Table 4, Fig. 3) revealed that haliangicin D (5) was the $4 E, 6 E$ isomer of 1 and that the concomitant minor isomer was cis-haliangicin $\mathrm{D}$ (cis-5). 
Table 3. ${ }^{13} \mathrm{C}$ NMR data for haliangicins $\mathrm{B}(\mathbf{3}) \sim \mathrm{D}(\mathbf{5})$ and their cis isomers in $\mathrm{CDCl}_{3}$.

\begin{tabular}{llll}
\hline & \multicolumn{3}{c}{$\delta_{\mathrm{c}}\left(\mathrm{mult}^{\mathrm{a}}{ }^{\mathrm{a}}\right.$} \\
Position & $\mathbf{3}[c i s-3]^{\mathrm{b}}$ & $\mathbf{4}[c i s-4]^{\mathrm{b}}$ & $\mathbf{5}[c i s-5]^{\mathrm{b}}$ \\
\hline 1 & $165.8(\mathrm{~s})$ & $166.1(\mathrm{~s})$ & $166.1(\mathrm{~s})$ \\
2 & $100.3(\mathrm{~d})$ & $95.4(\mathrm{~d})$ & $95.5(\mathrm{~d})$ \\
3 & $164.8(\mathrm{~s})$ & $166.6(\mathrm{~s})$ & $166.6(\mathrm{~s})$ \\
4 & $149.9(\mathrm{~s})$ & $150.7(\mathrm{~s})$ & $149.3(\mathrm{~s})$ \\
5 & $115.5(\mathrm{~d})$ & $103.4(\mathrm{~d})$ & $110.4(\mathrm{~d})$ \\
6 & $129.9(\mathrm{~s})$ & $129.2(\mathrm{~s})$ & $130.0(\mathrm{~s})$ \\
7 & $128.5[128.6](\mathrm{d})$ & $124.6(\mathrm{~d})$ & $125.2(\mathrm{~d})$ \\
8 & $120.1[120.3](\mathrm{d})$ & $120.4[120.6](\mathrm{d})$ & $120.5[120.7](\mathrm{d})$ \\
9 & $143.8(\mathrm{~s})$ & $141.0(\mathrm{~s})$ & $141.9(\mathrm{~s})$ \\
10 & $40.5[40.7](\mathrm{d})$ & $40.2[40.5](\mathrm{d})$ & $40.4[40.7](\mathrm{d})$ \\
11 & $44.0(\mathrm{t})$ & $44.0(\mathrm{t})$ & $44.1(\mathrm{t})$ \\
12 & $61.9[62.1](\mathrm{s})$ & $62.0(\mathrm{~s})$ & $62.0[62.1](\mathrm{s})$ \\
13 & $63.8[64.4](\mathrm{d})$ & $63.9[64.5](\mathrm{d})$ & $63.9[64.5](\mathrm{d})$ \\
14 & $133.5[133.7](\mathrm{d})$ & $133.6[133.8](\mathrm{d})$ & $133.6[133.8](\mathrm{d})$ \\
15 & $120.0[119.7](\mathrm{t})$ & $120.0[119.7](\mathrm{t})$ & $120.0[119.7](\mathrm{t})$ \\
$1-\mathrm{OMe}$ & $51.1(\mathrm{q})$ & $51.1(\mathrm{q})$ & $51.1(\mathrm{q})$ \\
$3-\mathrm{OMe}$ & $60.1(\mathrm{q})$ & $56.0(\mathrm{q})$ & $55.9(\mathrm{q})$ \\
$4-\mathrm{OMe}$ & $58.8(\mathrm{q})$ & $55.9(\mathrm{q})$ & $55.9(\mathrm{q})$ \\
$6-\mathrm{Me}$ & $23.2(\mathrm{q})$ & $22.9(\mathrm{q})$ & $14.8(\mathrm{q})$ \\
$9-\mathrm{Me}$ & $13.5[13.3](\mathrm{q})$ & $13.3(\mathrm{q})$ & $13.6(\mathrm{q})$ \\
$10-\mathrm{Me}$ & $19.4[19.5](\mathrm{q})$ & $19.3[19.4](\mathrm{q})$ & $19.3(\mathrm{q})$ \\
$12-\mathrm{Me}$ & $16.7[22.4](\mathrm{q})$ & $16.8[22.5](\mathrm{q})$ & $16.8[22.5](\mathrm{q})$ \\
\hline & $150 \mathrm{MHz}$ m & &
\end{tabular}

${ }^{a}$ Recorded at $150 \mathrm{MHz}$, multiplicity inferred using the DEPT pulse sequence.

${ }^{b}$ The cis isomers are minor in all cases in the ratio of 2:1 and the chemical shifts due to the cis isomers are shown in brackets if different from those due to the trans isomers.

\section{Discussion}

Haliangicin (1) is the first antibiotic isolated from a marine myxobacterium. ${ }^{8,9)}$ Until this discovery, all the myxobacterial antibiotics had originated from terrestrial myxobacteria. Haliangicin (1) inhibits the growth of a variety of fungi but is inactive against bacteria. It interfered with the electron flow within the cytochrome $b-c_{1}$ segment in the mitochondrial respiratory chains. ${ }^{8)}$ While exploring further antifungal substances from the haliangicinproducing myxobacterium $H$. ochraceum, we have been able to isolate several isomers of haliangicin (1) and have determined their structures. Haliangicin (1) and its isomers belong to the class of compounds that contain a $\beta$ - methoxyacrylate moiety, which exhibit antifungal activity. ${ }^{8)}$ To the best of our knowledge, all the antibiotics possessing a $\beta$-methoxyacrylate moiety have $E$ configuration, such as cystothiazoles, ${ }^{11,12)}$ myxothiazols, ${ }^{13)}$ and melithiazols. ${ }^{14,15)}$ It is interesting to note that one of our isolates, haliangicin $B$ (3), is the first example of a (Z)- $\beta$-methoxyacrylate of this class of antibiotics. Haliangicin (1) and its cis-isomer (2) show an almost identical activity against the fungus $P$ capsici. This observation indicates that the relative stereochemistry of the substituents on the epoxide ring, located far from the active center ( $\beta$-methoxyacrylate), plays no crucial role in the antifungal activity of the haliangicins. The antifungal activities of the cis-isomers of $3 \sim 5$, though pending because of the difficulty of isolation, are expected to be the same as those of the respective trans- 
Table 4. NOESY correlations for haliangicins $\mathbf{1} \sim \mathbf{5}$ in $\mathrm{CDCl}_{3}$.

\begin{tabular}{|c|c|c|c|c|c|}
\hline$\overline{\text { Position }}$ & & 2 & $3[\text { cis-3 }]^{b}$ & $4[c i s-4]^{b}$ & $5[\text { cis }-5]^{\mathrm{b}}$ \\
\hline 2 & 3-OMe & 3-OMe & $5,4-\mathrm{OMe}$ & & \\
\hline 5 & 8 & 8 & $2,8^{\mathrm{c}}, 3-\mathrm{OMe}$ & 8, 4-OMe, 6-Me & 7, 6-Me \\
\hline 7 & 6-Me, 9-Me & 6-Me, 9-Me & $6-\mathrm{Me}^{\mathrm{c}}, 9-\mathrm{Me}^{\mathrm{c}}$ & 6-Me, 9-Me & $5,9-\mathrm{Me}$ \\
\hline 8 & $5,10,10-\mathrm{Me}$ & $5,10,10-\mathrm{Me}$ & $5^{c}, 10^{c}$ & $5,10,10-\mathrm{Me}$ & $\begin{array}{l}10,6-\mathrm{Me} \\
10-\mathrm{Me}\end{array}$ \\
\hline 10 & $\begin{array}{l}8,11 \mathrm{~b}, 10-\mathrm{Me}, \\
12-\mathrm{Me}\end{array}$ & $\begin{array}{l}8,11,10-\mathrm{Me}, \\
12-\mathrm{Me}\end{array}$ & $\begin{array}{l}8^{\mathrm{c}}, 11,9-\mathrm{Me}, \\
10-\mathrm{Me}, 12-\mathrm{Me}\end{array}$ & $\begin{array}{l}8,11 \mathrm{~b}, 9-\mathrm{Me} \\
10-\mathrm{Me}, 12-\mathrm{Me}\end{array}$ & $\begin{array}{l}8,11 \mathrm{~b}, 10-\mathrm{Me} \\
12-\mathrm{Me}\end{array}$ \\
\hline $11 \mathrm{a}$ & $\begin{array}{l}\text { 10,11b, 13, } \\
10-\mathrm{Me}\end{array}$ & $\begin{array}{l}\text { 10,11b, 14, } \\
10-\mathrm{Me}\end{array}$ & $11 \mathrm{~b}, 13$ & $10,11 b, 13,[14]$ & $\begin{array}{l}10,11 \mathrm{~b}, 13, \\
{[14]}\end{array}$ \\
\hline $11 \mathrm{~b}$ & $10,11 \mathrm{a}, 12-\mathrm{Me}$ & $10,11 \mathrm{a}, 12-\mathrm{Me}$ & $10,11 \mathrm{a}$ & $10,11 \mathrm{a}$ & $10,11 \mathrm{a}$ \\
\hline 13 & $11 \mathrm{a}, 15 \mathrm{~b}, 10-\mathrm{Me}$ & $14,15 \mathrm{~b}, 12-\mathrm{Me}$ & $\begin{array}{l}\text { 11a, 15b, 10-Me, } \\
\text { [12-Me] }\end{array}$ & $14,15 \mathrm{~b}, 10-\mathrm{Me}$ & $\begin{array}{l}11,14,15 \mathrm{~b}, \\
10-\mathrm{Me},[12-\mathrm{Me}]\end{array}$ \\
\hline 14 & $15 \mathrm{a}, 12-\mathrm{Me}$ & $11 \mathrm{a}, 15 \mathrm{a}$ & $15 \mathrm{a}, 12-\mathrm{Me},[11 \mathrm{a}]$ & $15 \mathrm{a}, 12-\mathrm{Me},[11 \mathrm{a}]$ & $\begin{array}{l}\text { 13, 15a, 12-Me, } \\
{[11 \mathrm{a}]}\end{array}$ \\
\hline $15 \mathrm{a}$ & $14,15 b$ & $14,15 b$ & $14,15 b$ & $14,15 b$ & $14,15 b$ \\
\hline $15 b$ & $13,15 a$ & $13,15 \mathrm{a}$ & $13,15 \mathrm{a}$ & $13,15 \mathrm{a}$ & $13,15 \mathrm{a}$ \\
\hline 3-OMe & 2 & 2 & 5 & & 2, 6-Me \\
\hline 4-OMe & 6-Me & 6-Me & 2, 6-Me & 5 & 5 \\
\hline 6-Me & 7 & 7, 4-OMe & $7^{\mathrm{c}}, 4-\mathrm{OMe}$ & 5,7 & 5,8 \\
\hline 9-Me & $7,10,10-\mathrm{Me}$ & $7,10,10-\mathrm{Me}$ & $7^{\mathrm{c}}, 10,10-\mathrm{Me}$ & $7,10,10-\mathrm{Me}$ & $7,10-\mathrm{Me}$ \\
\hline 10-Me & $\begin{array}{l}8,10,11 \mathrm{a}, 13 \\
9-\mathrm{Me}\end{array}$ & $\begin{array}{l}8,10,11 \mathrm{a} \\
9-\mathrm{Me}\end{array}$ & $8^{\mathrm{c}}, 10,13,9-\mathrm{Me}$ & $8,10,13$ & $8,10,13,9-\mathrm{Me}$ \\
\hline $12-\mathrm{Me}$ & $10,11 \mathrm{~b}, 14$ & $10,11 \mathrm{~b}, 13$ & $10,11 b, 14,[13]$ & $10,11 b, 14,[13]$ & $\begin{array}{l}10,11 \mathrm{~b}, 14, \\
{[13]}\end{array}$ \\
\hline
\end{tabular}

The NOESY data around the epoxide moiety of 1 were not reported in ref. 9.

${ }^{\mathrm{b}}$ The specific correlations for the cis isomers are in brackets.

${ }^{c}$ Determined by measurement in $\mathrm{C}_{6} \mathrm{D}_{6}$.

Fig. 3. Important NOE correlations and the partial stereochemistry of haliangicin (1) and its isomers.
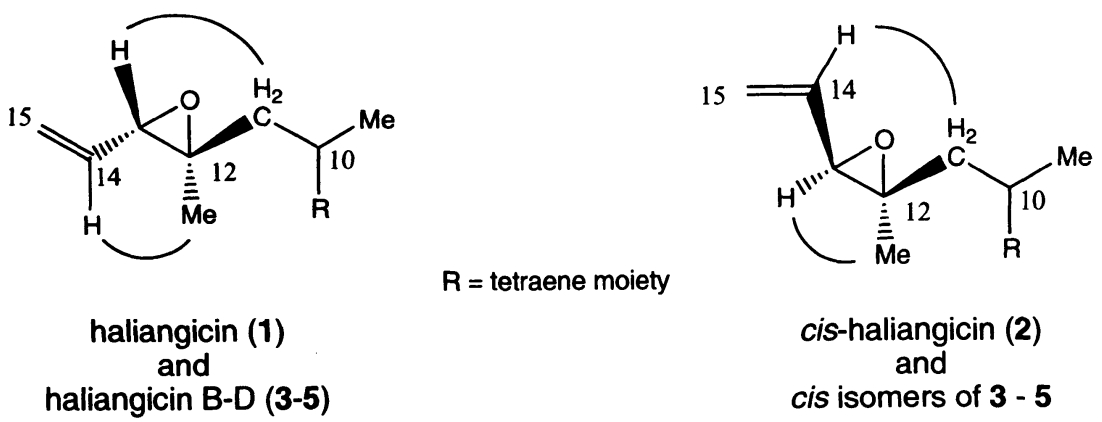
isomers $\mathbf{3} \sim 5$ from analogy to the relationship between 1 and 2. The geometrical isomers, haliangicins B (3) D (5), show lower activities than haliangicin (1), suggesting that the configurations of the conjugated tetraene moieties $(\mathrm{C} 2$, $\mathrm{C} 4$, and C6) are important, to some extent for the antifungal activities. Determination of the absolute configurations at the three stereogenic centers of haliangicin (1) is now in progress.

\section{Experimental}

\section{General}

Evaporation of solvents was carried out using a rotary evaporator under reduced pressure at temperatures around $30 \sim 38^{\circ} \mathrm{C}$. The residual samples were then vacuum dried. All the haliangicin samples were handled in dim light, or in the dark, with aluminum foil protection, and always stored as solutions in benzene at $-20^{\circ} \mathrm{C}$. Fuji Silysia silica gel BW-300 was employed for open column chromatography. Pre-coated silica gel $60 \mathrm{~F}_{254}$ plates (Merck) were used for thin-layer chromatography (TLC). HPLC was performed on a JASCO high-pressure gradient system equipped with PU980 pumps. Recycle HPLC was performed on a Shimadzu LC-8A high-pressure isocratic system. Optical rotations were measured with a JASCO DIP-370 digital polarimeter. IR spectra were recorded on a JASCO FT/IR-7000S spectrometer. UV spectra were recorded on a JASCO Ubest-50 UV/VIS spectrophotometer. NMR spectra were recorded on a Bruker ARX $400(400 \mathrm{MHz})$ or a Bruker ARX $600(600 \mathrm{MHz})$ spectrometer. NMR chemical shifts were referenced to the solvent peak of $\delta_{\mathrm{H}} 7.26$ (residual $\mathrm{CHCl}_{3}$ ) or 7.15 (residual $\mathrm{C}_{6} \mathrm{HD}_{5}$ ) for protons and $\delta_{\mathrm{C}} 77.0$ $\left(\mathrm{CDCl}_{3}\right)$ for ${ }^{13} \mathrm{C}$. Mass spectra were recorded on an Applied Biosystems Mariner Biospectrometry Workstation in the positive ESI mode. Polypropylene glycol (PPG) was used as an internal standard for high-resolution analysis.

\section{Isolation}

The production culture of the myxobacterium $H$. ochraceum AJ 13395 was performed under the conditions reported previously. ${ }^{8)}$ The bacterial cells and the adsorption resin SP 207 (Nippon Rensui) was separated from a culture broth (6 liters) by centrifugation and extracted with acetone $(600 \mathrm{ml})$ at room temperature for 3 days (one day should be sufficient). After filtration the filtrate was concentrated to obtain an oily crude sample $(590 \mathrm{mg})$. TLC analysis (hexane/EtOAc $4: 1$ ) of the crude sample showed the major spot of haliangicins at $\mathrm{Rf}=0.42$. The crude oil was chromatographed on silica gel $(35 \mathrm{~g})$ with $40 \mathrm{ml}$ of benzene, $40 \mathrm{ml}$ each of $1 \%, 2 \%, 4 \%, 10 \%, 20 \%, 50 \%$ of ethyl acetate in benzene, $40 \mathrm{ml}$ ethyl acetate, and then $40 \mathrm{ml}$ of methanol as successive eluants. The haliangicincontaining fraction $(138.7 \mathrm{mg}$ ) was combined with a second haliangicin-containing fraction $(77.8 \mathrm{mg})$ obtained similarly from another culture broth ( 3 liters) and was applied to silica gel $(10 \mathrm{~g})$ column chromatography with hexane/ EtOAc $4: 1$ as an eluant to obtain a yellowish orange oil $(184.7 \mathrm{mg})$. The oily material was then applied to preparative HPLC [Develosil ODS-5 $(20 \times 250 \mathrm{~mm})$, Nomura Chemical Ltd:; $\mathrm{UV}$ at $260 \mathrm{~nm}, 60 \% \mathrm{CH}_{3} \mathrm{CN}$, $9 \mathrm{ml} /$ minute] to obtain haliangicin $\mathrm{D}(\mathbf{5})(0.4 \mathrm{mg}, \mathrm{Rt}=40.2$ minutes), haliangicin $\mathrm{C}$ (4) (1.6 mg, $\mathrm{Rt}=47.9$ minutes), haliangicin (1) $(65.7 \mathrm{mg}, \mathrm{Rt}=54.2$ minutes $)$, and haliangicin $\mathrm{B}$ (3) (2.3 $\mathrm{mg}, \mathrm{Rt}=84.9$ minutes) as mixtures containing their corresponding cis-isomers, all as light yellow oils (Fig. 2). The mixture of 1 and the cis-isomer $\mathbf{2}$ was further subjected to recycle HPLC (Fig. 2) [Develosil ODS-5 $(20 \times 250 \mathrm{~mm})$, UV at $360 \mathrm{~nm}, 75 \% \mathrm{MeOH}, 9 \mathrm{ml} / \mathrm{minute}, 5-$ or 7-recycles for two injections] to obtain pure haliangicin (1) (36.5 mg) and cis-haliangicin (2) (19.6 mg) as light yellow oils.

Haliangicin (1): Light yellow oil, $[\alpha]_{\mathrm{D}}^{22}+34.6(c \quad 0.305$, $\mathrm{MeOH})$.

cis-Haliangicin (2): Light yellow oil, $[\alpha]_{\mathrm{D}}^{22}+29.3(c$ $0.212, \mathrm{MeOH})$; UV (MeOH) $\lambda_{\max } 245$ ( $\left.\varepsilon 11000, \mathrm{sh}\right), 295$ $(7600, \mathrm{sh}) \mathrm{nm}$; IR (film) $v_{\max } 1717,1617,1457,1143,1050$ and $927 \mathrm{~cm}^{-1}$; ESI-MS $m / z 377.2328(\mathrm{M}+\mathrm{H})^{+}$, calcd for $\mathrm{C}_{22} \mathrm{H}_{33} \mathrm{O}_{5}$ 377.2323. For ${ }^{1} \mathrm{H}$ and ${ }^{13} \mathrm{C}$ NMR and HMBC data refer to Table 1.

Mixture of Haliangicin B (3) and cis-3 (2:1 Ratio): Light yellow oil, $[\alpha]_{\mathrm{D}}^{22}+38(c 0.11, \mathrm{MeOH})$; UV $(\mathrm{MeOH})$ $\lambda_{\max } 254$ ( $\varepsilon$ 9500), 341 (11000) nm; IR (film) $v_{\max } 1720$, $1609,1456,1252,1159,1092$ and $1056 \mathrm{~cm}^{-1}$; ESI-MS $\mathrm{m} / \mathrm{z}$ $377.2337(\mathrm{M}+\mathrm{H})^{+}$, calcd for $\mathrm{C}_{22} \mathrm{H}_{33} \mathrm{O}_{5}$ 377.2323; HMBC correlations $\mathrm{H} 2 / \mathrm{C} 3, \mathrm{H} 2 / \mathrm{C} 4, \mathrm{H} 5 / \mathrm{C} 3, \mathrm{H} 5 / \mathrm{C} 4, \mathrm{H} 5 / \mathrm{C} 7, \mathrm{H} 5 / 6$ $\mathrm{Me}, \mathrm{H} 7 / \mathrm{C} 5, \mathrm{H} 7 / 6-\mathrm{Me}, \mathrm{H} 8 / \mathrm{C} 10, \mathrm{H} 8 / 9-\mathrm{Me}, \mathrm{H} 10 / \mathrm{C} 8$, $\mathrm{H} 10 / \mathrm{C} 9$, H10/C11, H10/C12, H10/9-Me, H10/10-Me, H11/C9, H11/C10, H11/C12, H11/C13, H11/10-Me, H11/12-Me, H13/C11, H13/C12, H13/C14, H13/C15, $\mathrm{H} 14 / \mathrm{C} 13, \mathrm{H} 15 / \mathrm{C} 13, \mathrm{H} 15 / \mathrm{C} 14,1-\mathrm{OMe} / \mathrm{C} 1,3-\mathrm{OMe} / \mathrm{C} 3,4-$ $\mathrm{OMe} / \mathrm{C} 4$, 6-Me/C5, 6-Me/C6, 6-Me/C7, 9-Me/C8, 9$\mathrm{Me} / \mathrm{C} 9$, 9-Me/C10, 10-Me/C9, 10-Me/C10, 10-Me/C11, 12-Me/C11, 12-Me/C12, 12-Me/C13. For ${ }^{1} \mathrm{H}$ and ${ }^{13} \mathrm{C}$ NMR data and NOESY correlations refer to Tables 2, 3, and 4, respectively.

Mixture of Haliangicin C (4) and cis-4 (2:1 Ratio): Light yellow oil, $[\alpha]_{D}^{22}-40(c 0.04, \mathrm{MeOH}) ; \mathrm{UV}(\mathrm{MeOH})$ $\lambda_{\max } 247$ ( $\varepsilon$ 9100), $277(9200) \mathrm{nm}$; IR (film) $v_{\max }$ 1726, $1603,1457,1262,1208,1168,1137,1047$ and $924 \mathrm{~cm}^{-1}$; 
ESI-MS $m / z \quad 377.2343(\mathrm{M}+\mathrm{H})^{+}$, calcd for $\mathrm{C}_{22} \mathrm{H}_{33} \mathrm{O}_{5}$ 377.2323; HMBC correlations $\mathrm{H} 2 / \mathrm{C} 3, \mathrm{H} 2 / \mathrm{C} 4, \mathrm{H} 5 / \mathrm{C} 3$, H5/C4, H5/C7, H5/6-Me, H7/C5, H7/C8, H7/C9, H7/6-Me, $\mathrm{H} 8 / \mathrm{C} 6, \mathrm{H} 8 / \mathrm{C} 7, \mathrm{H} 8 / \mathrm{C} 10, \mathrm{H} 8 / 9-\mathrm{Me}, \mathrm{H} 10 / \mathrm{C} 8, \mathrm{H} 10 / \mathrm{C} 9$, $\mathrm{H} 10 / \mathrm{C} 11$, H10/9-Me, H10/10-Me, H11/C9, H11/C10, H11/C12, H11/C13, H11/10-Me, H11/12-Me, H13/C12, $\mathrm{H} 13 / \mathrm{C} 14, \mathrm{H} 13 / \mathrm{C} 15, \mathrm{H} 14 / \mathrm{C} 13, \mathrm{H} 15 / \mathrm{C} 13, \mathrm{H} 15 / \mathrm{C} 14,1-$ $\mathrm{OMe} / \mathrm{C} 1,3-\mathrm{OMe} / \mathrm{C} 3,4-\mathrm{OMe} / \mathrm{C} 4,6-\mathrm{Me} / \mathrm{C} 5,6-\mathrm{Me} / \mathrm{C} 6,6-$ $\mathrm{Me} / \mathrm{C} 7,9-\mathrm{Me} / \mathrm{C} 8,9-\mathrm{Me} / \mathrm{C} 9,9-\mathrm{Me} / \mathrm{C} 10,10-\mathrm{Me} / \mathrm{C} 9,10-$ $\mathrm{Me} / \mathrm{C} 10,10-\mathrm{Me} / \mathrm{C} 11,12-\mathrm{Me} / \mathrm{C} 11,12-\mathrm{Me} / \mathrm{C} 12,12-\mathrm{Me} / \mathrm{C} 13$. For ${ }^{1} \mathrm{H}$ and ${ }^{13} \mathrm{C}$ NMR data and NOESY correlations refer to Tables 2, 3, and 4, respectively.

Mixture of Haliangicin D (5) and cis-5 (2:1 Ratio): Light yellow oil, $[\alpha]_{\mathrm{D}}^{22}-20(c 0.05, \mathrm{MeOH})$; UV $(\mathrm{MeOH})$ $\lambda_{\max } 286(\varepsilon 27000) \mathrm{nm}$; IR (film) $v_{\max } 1727,1653,1602$, 1457, 1261, 1166, 1136, 1047, 923 and $805 \mathrm{~cm}^{-1}$; ESI-MS $\mathrm{m} / \mathrm{z} 377.2341(\mathrm{M}+\mathrm{H})^{+}$, calcd for $\mathrm{C}_{22} \mathrm{H}_{33} \mathrm{O}_{5}$ 377.2323; HMBC correlations H2/C3, H2/C4, H5/C3, H5/C4, H5/C7, H5/6-Me, H7/C5, H7/C9, H7/6-Me, H8-/C10, H8/9-Me, $\mathrm{H} 10 / \mathrm{C} 8, \mathrm{H} 10 / \mathrm{C} 9, \mathrm{H} 10 / \mathrm{C} 11, \mathrm{H} 10 / 9-\mathrm{Me}, \mathrm{H} 10 / 10-\mathrm{Me}$, $\mathrm{H} 11 / \mathrm{C} 10, \mathrm{H} 11 / \mathrm{C} 12, \mathrm{H} 11 / \mathrm{C} 13, \mathrm{H} 11 / 10-\mathrm{Me}, \mathrm{H} 11 / 12-\mathrm{Me}$, $\mathrm{H} 13 / \mathrm{C} 14, \mathrm{H} 13 / \mathrm{C} 15, \mathrm{H} 14 / \mathrm{C} 13, \mathrm{H} 15 / \mathrm{C} 13,1-\mathrm{OMe} / \mathrm{C} 1,3-$ $\mathrm{OMe} / \mathrm{C} 3,4-\mathrm{OMe} / \mathrm{C} 4,6-\mathrm{Me} / \mathrm{C} 5,6-\mathrm{Me} / \mathrm{C} 6$, 6-Me/C7, 9$\mathrm{Me} / \mathrm{C} 8,9-\mathrm{Me} / \mathrm{C} 9,9-\mathrm{Me} / \mathrm{C} 10,10-\mathrm{Me} / \mathrm{C} 9,10-\mathrm{Me} / \mathrm{C} 10,10-$ $\mathrm{Me} / \mathrm{C} 11,12-\mathrm{Me} / \mathrm{C} 11,12-\mathrm{Me} / \mathrm{C} 12,12-\mathrm{Me} / \mathrm{C} 13$. For ${ }^{1} \mathrm{H}$ and ${ }^{13} \mathrm{C}$ NMR data and NOESY correlations refer to Tables 2, 3 and 4 , respectively.

\section{Assay Method}

The antifungal activity of the haliangicins was evaluated by a paper disc assay using the phytopathogenic fungus Phytophthora capsici. Since this filamentous fungus rarely produces spores, the activity was evaluated not by MIC but by the observation of aversion to a paper disc impregnated with a test sample. A piece of agar, $5 \mathrm{~mm}$ in diameter, containing mycelia of $P$. capsici previously grown on a synthetic agar medium was placed onto the center of a plate $(9 \mathrm{~cm}$ in diameter) of the same agar medium (1 liter medium containing: sucrose $10 \mathrm{~g}$, monosodium glutamate monohydrate $1.5 \mathrm{~g}, \mathrm{KH}_{2} \mathrm{PO}_{4} 0.5 \mathrm{~g}, \mathrm{MgSO}_{4} \cdot 7 \mathrm{H}_{2} \mathrm{O} 0.25 \mathrm{~g}$, $\mathrm{CaCl}_{2} 0.1 \mathrm{~g}$, agar $10 \mathrm{~g}$, thiamine hydrochloride $1 \mathrm{mg}$, $\mathrm{Na}_{2} \mathrm{~B}_{4} \mathrm{O}_{7} \cdot 10 \mathrm{H}_{2} \mathrm{O} \quad 0.088 \mathrm{mg}, \quad \mathrm{CuSO}_{4} \cdot 5 \mathrm{H}_{2} \mathrm{O} \quad 0.393 \mathrm{mg}$, $\mathrm{Fe}_{2}\left(\mathrm{SO}_{4}\right)_{3} \cdot 9 \mathrm{H}_{2} \mathrm{O} \quad 0.91 \mathrm{mg}, \quad \mathrm{MnCl}_{2} \cdot 4 \mathrm{H}_{2} \mathrm{O} \quad 0.072 \mathrm{mg}$, $\mathrm{Na}_{2} \mathrm{MoO}_{4} \cdot 2 \mathrm{H}_{2} \mathrm{O} 0.05 \mathrm{mg}, \mathrm{ZnSO}_{4} \cdot 7 \mathrm{H}_{2} \mathrm{O} 4.403 \mathrm{mg}$, EDTA $\cdot$ $2 \mathrm{Na} 5 \mathrm{mg}$ ). After incubation at $25^{\circ} \mathrm{C}$ with $60 \%$ humidity for 2 days in the dark, the colony grew to a size of about $3 \sim 4 \mathrm{~cm}$ in diameter. Each paper disc ( $8 \mathrm{~mm}$ in diameter), which was impregnated with an EtOAc solution of a known amount of a sample and dried in vacuo, was placed one $\mathrm{cm}$ away from the edge of the colony. After incubation under the same conditions for an additional 29 hours when the edge of the colony reached the edge of the paper disc of the control, the distance between the edge of the colony and the paper disc was measured. The control disc was made by in vacuo drying of an EtOAc-containing paper disc.

\section{Acknowledgements}

This work was supported in part by the Fujisawa Foundation and by KAKENHI (12480172) from JSPS. BANGI A. KUNDIM is grateful for the financial support provided by the Ministry of Education, Culture, Sports, Science and Technology, Japan, through a Japanese Government Scholarship.

\section{References}

1) Reichenbach, H.; K. Gerth, H. IrschiK, B. KunZe \& G. HÖFLE: Myxobacteria: a source of new antibiotics. Trends Biotechnol. 6: 115 121, 1998

2) Reichenbach, H. \& G. HöFle: Production of bioactive secondary metabolites. In Myxobacteria II, Eds., M. DWORKIN \& D. KAISER, pp. 347 397, American Society for Microbiology, Washington, 1993

3) Reichenbach, H. \& G. HöFle: Myxobacteria as producers of secondary metabolites. In Drug discovery from nature, Eds., S. GRABLEY \& R. THIERICKE, pp. 149 179, Springer, Berlin, Heidelberg, New York, 1999

4) Höfle, G.; K. Gerth, N. Bedorf, H. Steinmetz, D. Schomburg \& H. ReICHENBACH: Epothilone A and BNovel 16-membered macrolides with cytotoxic activity: Isolation, crystal structure, and conformation in solution. Angew. Chem. Int. Ed. Engl. 35: 1567 1569, 1996

5) Gerth, K.; N. Bedorf, G. Höfle, H. Irschik \& H. REICHENBACH: Epothilons A and B: Antifungal and cytotoxic compounds from Sorangium cellulosum (Myxobacteria). Production, physico-chemical and biological properties. J. Antibiotics 49: 560 563, 1996

6) Bollag, D. M.; P. A. Mcqueney, J. Zhu, O. Hensens, L. Koupal, J. Liesch, M. Goetz, E. Lazarides \& C. M. Woods: Epothilones, a new class of microtubulestabilizing agents with a taxol-like mechanism of action. Cancer Res. 55: 2325 2333, 1995

7) Iizuka, T.; Y. Jojima, R. Fudou \& S. Yamanaka: Isolation of myxobacteria from the marine environment. FEMS Microbiol. Lett. 169: 317 322, 1998

8) Fudou, R.; T. IIzuKa \& S. YamanaKa: Haliangicin, a novel antifungal metabolite produced by a marine myxobacterium. 1. Fermentation and biological characteristics. J. Antibiotics 54: 149 152, 2001

9) Fudou, R.; T. IIzuKa, S. SATo, T. Ando, N. Shimba \& S. YAMANAKA: Haliangicin, a novel antifungal metabolite produced by a marine myxobacterium. 2. Isolation and structural elucidation. J. Antibiotics 54: 153 156, 2001

10) Fudou, R.; Y. JoJima, T. IIZUKA \& S. YAMANAKA: Haliangium ochraceum gen. nov., sp. nov. and Haliangium tepidum sp. nov.: Novel moderately halophilic myxobacteria isolated from coastal saline environments. J. Gen. Appl. Microbiol. 48: 109 115, 2002

11) Ojika, M.; Y. Suzuki, A. Tsukamoto, Y. Sakagami, R. 
Fudou, T. Yoshimura \& S. YamanaKa: Cysthothiazoles $A$ and $B$, new bithiazole-type antibiotics from the myxobacterium Cystobacter fuscus. J. Antibiotics 51: 275 281, 1998

12) Suzuki, Y.; M. OjiKa, Y. Sakagami, R. Fudou \& S. YAMANAKA: Cystothiazoles $\mathrm{C} \sim \mathrm{F}$, new bithiazole-type antibiotics from the myxobacterium Cystobacter fuscus. Tetrahedron 54: 11399 11404, 1998

13) Trowitzsch, W.; G. Reifenstahl, V. Wray \& K. Gerth: Myxothiazol, an antibitotic from Myxococcus fulvus (Myxobacterales). II. Structure elucidation. J. Antibiotics
33: $1480 \sim 1490,1980$

14) Sasse, F.; B. Böhlendorf, M. Hermann, B. Kunze, E. Forche, H. Steinmetz, G. Höfle \& H. Reichenbach: Melithiazols, new $\beta$-methoxyacrylate inhibitors of the respiratory chain isolated from myxobacteria. J. Antibiotics 52: 721 729, 1999

15) Böhlendorf, B.; M. Herrmann, H.-J. Hecht, F. Sasse, E. Forche, B. Kunze, H. Reichenbach \& G. Höfle: Antibiotics from gliding bacteria, 85. Melithiazols $\mathrm{A} \sim \mathrm{N}$ : New antifungal $\beta$-methoxyacrylates from myxobacteria. Eur. J. Org. Chem. 2601 2608, 1999 